\title{
Klasifikasi Chest X-Ray Images Berdasarkan Kriteria Gejala Covid-19 Menggunakan Convolutional Neural Network
}

\author{
${ }^{1}$ Vina Ayumi, ${ }^{2}$ Ida Nurhaida \\ ${ }^{1,2}$ Fakultas Ilmu Kompututer, Universitas Mercu Buana, Jakarta, Indonesia \\ ${ }^{l}$ vina.ayumi@mercubuana.ac.id; ${ }^{2}$ ida.nurhaida@mercubuana.ac.id
}

\begin{tabular}{l} 
Article Info \\
\hline Article history: \\
Received, 02-04-2021 \\
Revised, 01-06-2021 \\
Accepted, 14-06-2021 \\
\hline Kata Kunci: \\
COVID-19 \\
deep learning \\
convolutional neural network \\
Chest X-Ray \\
\hline \hline
\end{tabular}

\begin{abstract}
ABSTRAK
Deteksi dini terhadap adanya indikasi pasien dengan gejala COVID-19 perlu dilakukan untuk mengurangi penyebaran virus. Salah satu cara yang dapat dilakukan untuk mendeteksi virus COVID-19 adalah dengan cara mempelajari citra chest $x$-ray pasien dengan gejala Covid-19. Citra chest $x$-ray dianggap mampu menggambarkan kondisi paru-paru pasien COVID-19 sebagai alat bantu untuk diagnosa klinis. Penelitian ini mengusulkan pendekatan deep learning berbasis convolutional neural network $(\mathrm{CNN})$ untuk klasifikasi gejala COVID-19 melalui citra chest $X$-Ray. Evaluasi performa metode yang diusulkan akan menggunakan perhitungan accuracy, precision, recall, flscore, dan cohens kappa. Penelitian ini menggunakan model CNN dengan 2 lapis layer convolusi dan maxpoling serta fully-connected layer untuk output. Parameter-parameter yang digunakan diantaranya batch_size $=32$, epoch $=$ 50, learning_rate $=0.001$, dengan optimizer yaitu Adam. Nilai akurasi validasi (val_acc) terbaik diperoleh pada epoch ke-49 dengan nilai 0.9606, nilai loss validasi (val_loss) 0.1471, akurasi training (acc) 0.9405, dan loss training (loss) 0.2558 .
\end{abstract}

\section{ABSTRACT}

Early detection of COVID-19 symptoms needs to be done to reduce the spread of the virus. One way that can be done to detect the COVID-19 virus is by studying chest $\mathrm{x}$-ray images of patients with Covid-19 symptoms. Chest $\mathrm{x}$-ray images are considered capable of describing the lungs of COVID-19 patients as a tool for clinical diagnosis. This study proposes a convolutional neural network $(\mathrm{CNN})$ based deep learning approach to classify symptoms of COVID-19 through chest X-Ray images. The proposed method's performance evaluation will calculate accuracy, precision, recall, f1-score, and Cohen's kappa. This study uses a CNN model with two layers of convolution and maxpooling layers and a fully connected layer for output. The parameters used include batch_size $=32$, epoch $=50$, learning_rate $=0.001$, with the optimizer, namely Adam. The best validation accuracy was obtained at the 49th epoch with a value of 0.9606 , the value of validation loss 0.1471 , training accuracy (acc) 0.9405 , and loss training 0.2558 .

This is an open access article under the CC BY-SAlicense.
COVID-19

deep learning

Chest X-Ray

\section{Penulis Korespondensi:}

Vina Ayumi,

Fakultas Ilmu Komputer

Universitas Mercu Buana, Jakarta, Indonesia

Email: vina.ayumi@mercubuana.ac.id

\section{PENDAHULUAN}

Masyarakat dan pemerintah Indonesia saat ini sedang menghadapi penyebaran wabah penyakit berupa sindrom pernapasan parah yang disebabkan oleh virus. Virus yang dikenal dengan nama COVID-19 (SARSCoV-2) ini pertama kali ditemukan di Wuhan, China pada akhir tahun 2019. Penyakit yang disebabkan oleh COVID-19 ini telah menyebar ke negara lain dengan jumlah pasien yang terus meningkat [1]. Tingkat penyebaran virus ini cukup cepat sehingga World Health Organization (WHO) telah menetapkan wabah ini sebagai sebuah pandemi penyakit. Penyebaran SARS-CoV-2 atau COVID-19 telah menyebar luas dan cepat 
ke negara di seluruh dunia juga telah menyebabkan fasilitas kesehatan menjadi terbatas dan perekonomian terganggu [2], [3].

Virus SARS-CoV-2 adalah jenis virus baru yang sedang diteliti agar penyebarannya dapat dikendalikan dan pasien yang terjangkit virus ini dapat disembuhkan dengan cepat [4]. Pada bulan Oktober 2020, pasien yang menderita penyakit COVID-19 meningkat signifikan menjadi 35.248.330 orang. Riset mengenai COVID19 saat ini banyak fokus pada penemuan vaksin yang diharapkan dapat mengurangi angka kematian akibat virus COVID-19 [2].

Untuk membantu dokter agar dapat menangani banyak pasein, beberapa penelitian mencoba mengembangan computer-aided diagnosis (CAD). Perangkat berbasis artificial intelligence diharapkan dapat digunakan oleh dokter untuk mendiagnosis penyakit COVID-19 melalui pemeriksaan chest X-ray secara cepat dan otomatis [5], [6]. Untuk mendukung pengembangan computer-aided diagnosis (CAD), perlu adanya riset dasar mengenai implementasi artificial intelligence untuk chest X-ray screening terhadap COVID-19 [7].

Penelitian mengenai deteksi COVID-19 berdasarkan chest X-ray telah dilakukan banyak peneliti dengan menggunakan pendekatan deep learning [2], [8]-[10]. Penelitian oleh Narin et al. (2020) membahas mengenai penggunaan model CNN antara lain ResNet50, ResNet101, ResNet152, InceptionV3 dan Inception-ResNetV2 untuk mengklasifikasi dataset berdasarkan empat kelas yaitu COVID-19, normal (sehat), viral pneumonia dan bacterial pneumonia menggunakan 5-fold cross validation. Hasil terbaik didapatkan dengan menggunakan model ResNet50 yang mencapai akurasi rata-rata 98,43\% [2].

Penelitian oleh Abbas et al. (2020) mengusulkan implementasi deep CNN yaitu Decompose, Transfer, and Compose (DeTraC) untuk klasifikasi citra chest X-ray pasien dengan mendapatkan akurasi terbaik sebesar 95.12\% [8]. Mahmud et al. (2020) melakukan riset implementasi algoritma convolutional neural network (CNN) dengan arsitektur CovXNet dan mendapatkan akurasi rata sebesar 94,8\% untuk klasifikasi citra chest $x$-ray pasien berdasarkan kategori normal dan (viral/bacterial) pneumonia [9]. Penelitian oleh Marques et al. (2020) membahas mengenai implementasi CNN dengan arsitektur EfficientNet dan 10-fold stratified untuk cross-validation. Riset ini mendapatkan hasil akurasi klasifikasi citra chest $x$-ray dengan kategori COVID-19, pneumonia dan normal (multi-class) sebesar 96.70\% [10].

Berdasarkan latar belakang diatas, penelitian ini mengusulkan riset tentang klasifikasi chest $\mathrm{x}$-ray image berdasarkan kriteria gejala COVID-19 menggunakan convolutional neural network dengan dataset yang berbeda untuk melihat apakah akurasi CNN dapat stabil dan berkinerja dengan baik.

\section{METODE PENELITIAN}

Penelitian ini bertujuan untuk melakukan klasifikasi citra chest $x$-ray berdasarkan kriteria gejala COVID19 menggunakan convolutional neural network. Pada studi ini, dataset yang digunakan adalah citra chest $x$-ray dari pasien COVID-19 yang dikumpulkan dari online resource [11]. Untuk menyelesaikan penelitian sesuai dengan tujuan riset, penelitian ini akan dilakukan dalam 5 tahapan yang dapat dilihat pada Gambar berikut.

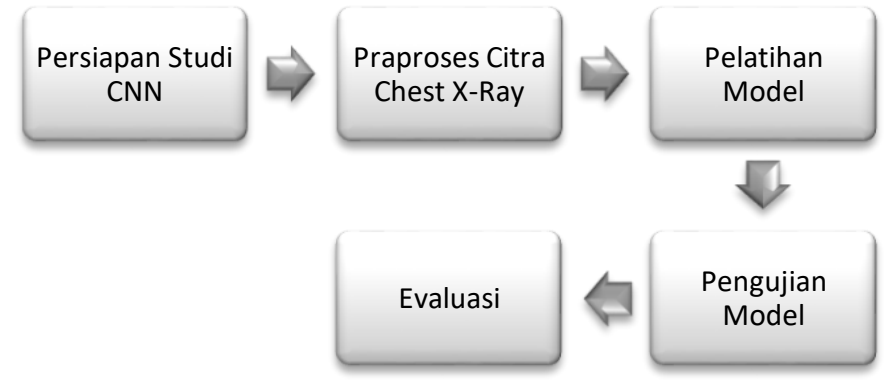

Gambar 1 Tahap Penelitian

Tahap pertama adalah melakukan studi literatur terkait performa model deep learning yang diusulkan pada studi kasus lain. Tahap kedua adalah melakukan praproses pada dataset citra. Praproses yang dilakukan untuk mempersiapkan data agar siap digunakan pada proses selanjutnya. Praproses dilakukan dengan meningkatkan kontras citra serta mengubah ke dalam format dan ukuran yang sesuai untuk deteksi COVID-19. Sebanyak 5800 citra chest $x$-ray akan digunakan pada penelitian ini. Salah satu bentuk atau contoh citra antara lain dapat dilihat pada Gambar berikut ini [11]. 


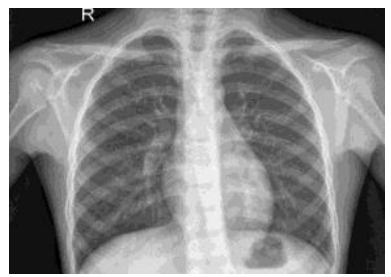

\section{Gambar 2 Contoh Data Citra Chest X-Ray}

Tahap ketiga adalah melakukan pelatihan model menggunakan CNN dengan layer input yaitu dua lapis layer convolusi dan maxpoling serta fully-connected layer untuk outpunya. Setelah model berhasil diperoleh, tahap keempat adalah menguji model menggunakan data pengujian yang sudah disiapkan dari tahap kedua. Tahap akhir adalah evaluasi yang dilakukan untuk mengetahui performansi dari model yang telah dibuat. Evaluasi dilakukan dengan menghitung tingkat kesalahan model dalam memprediksi data pengujian (error rate). Kriteria evaluasi yang digunakan dalam penelitian ini antara lain accuracy, recall, precision, dan F1-Score.

\section{HASIL DAN ANALISIS}

\subsection{Dataset}

Dataset yang digunakan adalah COVID-19 Radiography Database. Dataset ini merupakan dataset yang dibuat oleh tim peneliti dari Qatar University dan University of Dhaka berkolaborasi dengan beberapa tenaga medis [11]. Gambar 3 merupakan contoh dari dataset dengan label COVID-19 dan Normal.

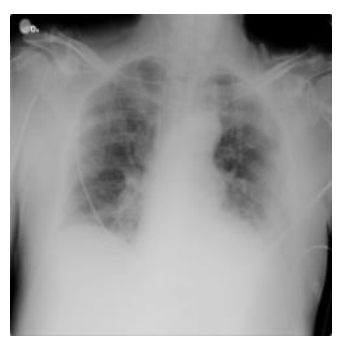

COVID-19

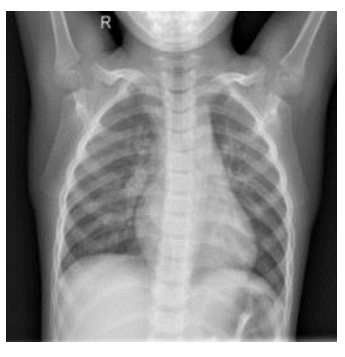

Normal

\section{Gambar 3 Contoh Data Citra Chest X-Ray}

Penelitian ini menggunakan dataset terdiri dari 2 kelas yaitu kasus positif COVID-19 dengan jumlah citra 1200 data dan normal dengan jumlah citra sebanyak 1341 data. Seluruh gambar pada dataset ini dalam format Portable Network Graphics (PNG) dengan resolusi 1024x1024 piksel dan 256x256 piksel. Pada penelitian ini kami mengambil hanya 2 kelas saja yaitu kelas COVID-19 dan kelas Normal, sehingga jumlah data total adalah 2541.

\subsection{Praproses}

Pada penelitian ini kami membagi dataset menjadi $80 \%$ data training dan $20 \%$ data validation. Sehingga jumlah data training adalah 2033 citra dan jumlah data validation adalah 508 citra. Kemudian kami melakukan data augmentasi untuk menambah jumlah sampel data dengan melakukan random transformasi seperti (rescale, zoom, flip, dan lain-lain) pada citra sehingga tidak akan ada citra yang duplikat. Tahap augmentasi ini cukup penting pada kasus dimana dataset yang dimiliki terbatas. Hal ini akan membuat proses generalisasi menjadi lebih baik dan mencegah overfitting. Pada penelitian ini augmentasi dilakukan pada dataset training dan validation berupa 10 transformasi yaitu: rotation_range, width_shift_range, height_shift_range, brightness_range, shear_range, zoom_range, channel_shift_range, horizontal_flip dan vertical_flip, rescale.

Augmentasi dilakukan dengan menggunakan Keras ImageDataGenerator dan flow_from_directory() API. API ini membutuhkan data untuk dibagi menjadi direktori /train dan /validation, dan dibawah tiap direktori terdapat sub-direktori untuk tiap kelas contohnya train/NORMAL dan train/COVID, begitu juga untuk direktori /validation. Semua gambar kemudian dimasukkan kedalam sub-direktori tersebut sesuai dengan nama kelas masing-masing. Kemudian semua image diseragamkan ukurannya sebesar 224x224 pixel.

\subsection{Pelatihan dan Pengujian Model}

Model yang kami gunakan adalah CNN model dengan layer input: 2 lapis layer convolusi dan maxpoling serta fully-connected layer untuk output, diperlihatkan pada Gambar 4 berikut ini. 


\begin{tabular}{|c|c|c|}
\hline \multirow{2}{*}{\multicolumn{3}{|c|}{ 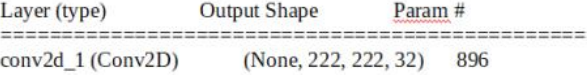 }} \\
\hline & & \\
\hline \multicolumn{3}{|c|}{$\begin{array}{lll}\text { activation_1 (Activation) } & \text { (None, 222, 222, 32) } & 0\end{array}$} \\
\hline \multicolumn{3}{|c|}{$\begin{array}{l}\text { max_pooling2d_1 (MaxPooling2 (None, 111, 111, 32) } \\
0\end{array}$} \\
\hline conv2d_2 (Conv2D) & (None, $110,110,64)$ & 8256 \\
\hline activation_2 (Activation) & (None, $110,110,64)$ & 0 \\
\hline \multicolumn{3}{|c|}{$\begin{array}{l}\text { max_pooling2d_2 (MaxPooling2 (None, 55, 55, 64) } \\
0\end{array}$} \\
\hline flatten_1 (Flatten) & None, 193600) & \\
\hline dense_1 (Dense) & (None, 256) & 61856 \\
\hline activation_3 (Activation) & (None, 256) & \\
\hline dropout_1 (Dropout) & (None, 256) & \\
\hline $\begin{array}{l}\text { dense_2 (Dense) } \\
=====-=============\end{array}$ & $\begin{array}{l}\text { None, 3) } \\
=================-\end{array}$ & $===========$ \\
\hline $\begin{array}{l}\text { Total params: } 49,571,779 \\
\text { Trainable params: } 49,571,7 \\
\text { Non-trainable params: } 0\end{array}$ & 779 & \\
\hline
\end{tabular}

Gambar 4 Model CNN yang digunakan

Parameter-parameter yang digunakan diantaranya batch_size $=32$, epoch $=50$, learning_rate $=0.001$, dengan optimizer yaitu Adam. Hasil training dan validasi yang didapatkan dengan epoch 50 dapat dilihat pada Gambar 4 berikut.

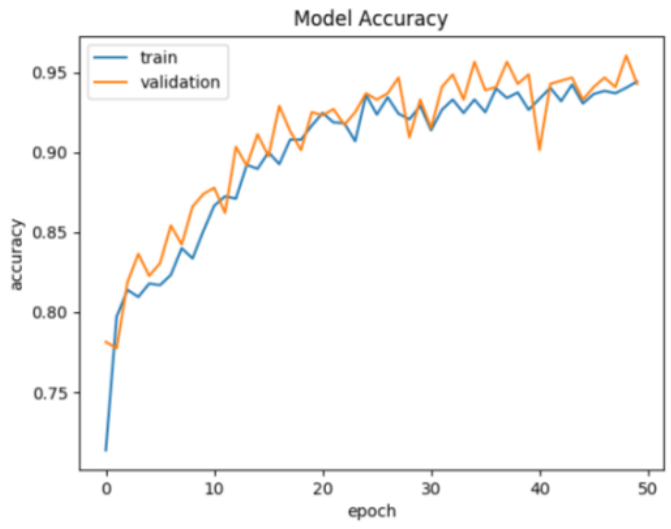

Gambar 5 Akurasi training dan validasi selama 50 epoch

Gambar 5 memperlihatkan grafik kenaikan akurasi training dan validasi dari epoch 0-50, dapat dilihat bahwa akurasi validasi memiliki nilai yang lebih tinggi daripada akurasi training hampir untuk setiap epoch. Hal ini menunjukkan bahwa model dapat melakukan generalisasi dengan baik. Masing-masing akurasi baik training maupun validasi mengalami peingkatan yang fluktuatif. Ini menunjukkan bahwa model belum mencapai konvergen, hal ini dapat terjadi karena nilai parameter yang digunakan belum fit dengan data yang dilatih, misalnya nilai learning_rate atau nilai batch_size yang terlalu kecil, optimizer yang digunakan belum tepat, atau jumlah iterasi (epoch) yang dilakukan belum cukup.

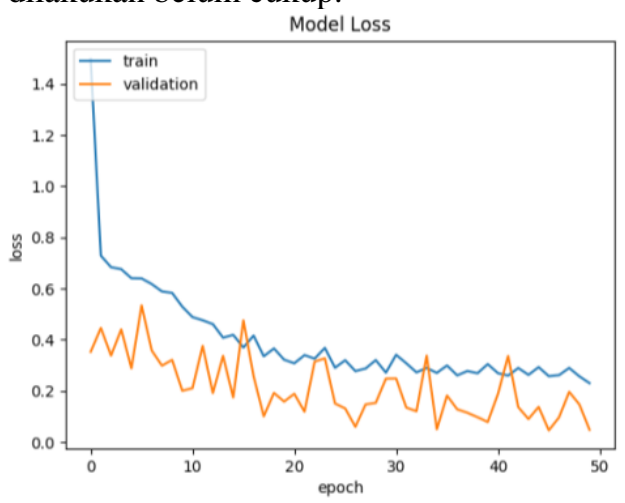

Gambar 6 Loss training dan validasi selama 50 epoch 
JSAI: Journal Scientific and Applied Informatics

Vol. 4, No. 2, Juni 2021, hal. 147 153

E-ISSN: 2614-3054; P-ISSN: 2614-3062, accredited by Kemenristekdikti, Sinta 5

DOI: 10.36085

Begitu pula dengan Gambar 6, memperlihatkan grafik penurunan loss dari epoch ke-1 sampai dengan ke50. Ditunjukkan grafik bahwa nilai loss validasi lebih rendah daripada nilai loss training hampir untuk tiap epoch. Namun penurunan yang terjadi masih fluktuatif.

\subsection{Evaluasi Hasil}

Akurasi validasi (val_accuracy) dan loss validasi (val_loss) terbaik diperoleh pada epoch ke-49 dengan nilai 0.9606 dan 0.1471 , akurasi training (acc) 0.9405 , dan loss training (loss) 0.2558 , dengan nilai precision: 0.9650, recall: 0.9650, fl-score: 0.9650 , dan cohens kappa: 0.9297 . Hasil evaluasi menunjukkan, model yang digunakan dapat mengenali data yang belum diketahui (unseen data) dengan sangat baik, jika dilihat dari nilai akurasi validasi yang dihasikan yaitu lebih dari $96 \%$. Hasil juga menunjukkan model dapat melakukan generalisasi dengan baik, dapat dilihat dari nilai akurasi validasi yang lebih tinggi dari pada nilai akurasi training. Selain itu nilai precision, recall, fl-score, dan cohens kappa yang dihasilkan juga cukup tinggi, ini menandakan model dapat mengenali dua kelas dengan berimbang, baik untuk kelas COVID-19 maupun kelas Normal.

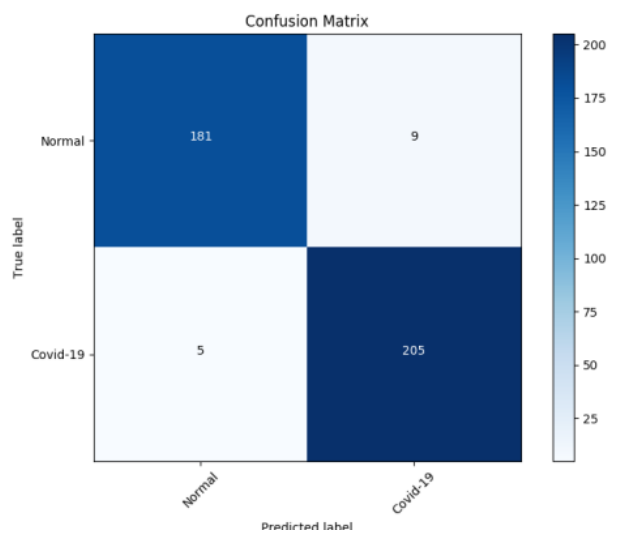

Gambar 7. Confusion matrix hasil prediksi pada data validasi

Gambar 7 memperlihatkan confusion matrix hasil prediksi pada data validasi. Pada confusion matrix terlihat bahwa hasil prediksi benar untuk kelas Normal adalah 181, sedangkan yang salah prediksi sebanyak 9 kesalahan. Untuk kelas COVID-19 hasil prediksi benar adalah 205, sedangkan yang salah prediksi sebanyak 5 kesalahan.

Model predictions (blue: correct, red: incorrect)
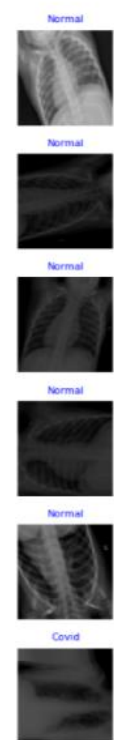
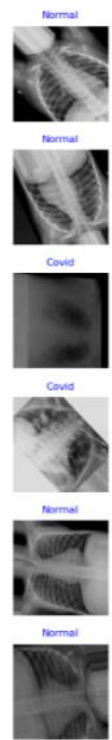
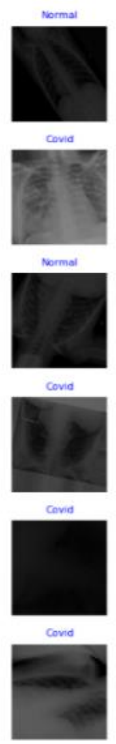

Keterangan: (label biru: benar terprediksi, label merah: salah terprediksi)
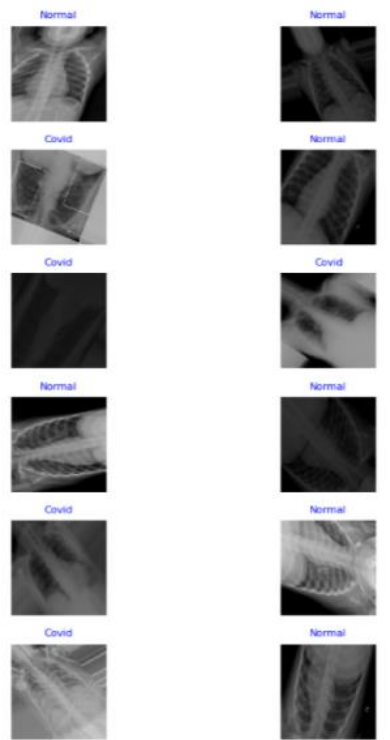

Gambar 8 Visualisasi Hasil Prediksi pada Data Validasi 
Gambar 8 memperlihatkan contoh hasil prediksi yang dilakukan pada 30 data validasi yang terdiri dari dua kelas COVID-19 dan Normal, dimana untuk label berwarna biru artinya benar terprediksi, sedangkan berwarna merah artinya salah terprediksi. Pada gambar diatas seperti kita lihat, sebanyak 30 citra semua dapat diprediksi dengan benar, dapat dilihat dari tidak ada label yang berwarna merah.

\section{KESIMPULAN}

Penelitian ini mengusulkan pendekatan deep learning berbasis Convolutional Neural Network untuk klasifikasi gejala COVID-19 melalui citra chest $x$-ray. Data yang digunakan dalam penelitian ini adalah data publik berupa citra chest $X$-Ray. Evaluasi performa metode yang diusulkan akan menggunakan perhitungan accuracy, precision, recall, fl-score, dan cohens kappa.

Penelitian ini menggunakan model CNN dengan 2 lapis layer convolusi dan maxpoling serta fullyconnected layer untuk outputnya. Parameter-parameter yang digunakan diantaranya batch_size $=32$, epoch $=$ 50, learning_rate $=0.001$, dengan optimizer yaitu Adam. Hasil pelatihan menunjukkan, model dapat melakukan generalisasi dengan baik, hal ini dapat dilihat dari nilai akurasi validasi yang memiliki nilai lebih tinggi daripada akurasi training hampir untuk setiap epoch.

Hasil pelatihan menunjukkan, masing-masing akurasi baik training maupun validasi mengalami peningkatan yang fluktuatif untuk setiap epoch, ini menunjukkan bahwa model yang digunakan belum mencapai konvergen, hal ini dapat terjadi karena nilai parameter yang digunakan belum fit dengan data yang dilatih, dan/ atau jumlah iterasi (epoch) yang dilakukan belum cukup. Nilai akurasi validasi (val_acc) terbaik diperoleh pada epoch ke-49 dengan nilai 0.9606, nilai loss validasi (val_loss) 0.1471 , akurasi training (acc) 0.9405 , dan loss training (loss) 0.2558 .

Walaupun model yang digunakan belum cukup konvergen namun hasil evaluasi menunjukkan model yang digunakan dapat mengenali data yang belum diketahui (unseen data) dengan sangat baik, jika dilihat dari nilai akurasi validasi yang dihasikan yaitu lebih dari 96\%. Hasil juga menunjukkan model dapat melakukan generalisasi dengan baik, dapat dilihat dari nilai akurasi validasi yang lebih tinggi dari pada nilai akurasi training. Selain itu nilai precision, recall, fl-score, dan cohens kappa yang dihasilkan juga cukup tinggi, yaitu precision: 0.9650 , recall: 0.9650, fl-score: 0.9650, dan cohens kappa: 0.9297, ini menandakan model dapat mengenali dua kelas dengan berimbang, baik untuk kelas COVID-19 maupun kelas Normal.

Penelitian selanjutnya kami akan menambah data dan melakukan serangkaian optimaasi parameter untuk memaksimalkan performansi dari model yang diusulkan serta membandingkan dengan state of the art yang ada.

\section{UCAPAN TERIMA KASIH}

Terima kasih kepada Pusat Penelitian dan Fakultas Ilmu Komputer, Universitas Mercu Buana yang telah mendukung pelaksanaan penelitian ini.

\section{REFERENSI}

[1] M. A. Shereen, S. Khan, A. Kazmi, N. Bashir, and R. Siddique, "COVID-19 infection: Origin, transmission, and characteristics of human coronaviruses," J. Adv. Res., 2020.

[2] A. Narin, C. Kaya, and Z. Pamuk, "Automatic detection of coronavirus disease (covid-19) using X-ray images and deep convolutional neural networks," arXiv Prepr. arXiv2003.10849, 2020.

[3] L. Yan et al., "Prediction of criticality in patients with severe Covid-19 infection using three clinical features: a machine learning-based prognostic model with clinical data in Wuhan," MedRxiv, 2020.

[4] D. S. Jones, "History in a crisis-lessons for Covid-19," N. Engl. J. Med., vol. 382, no. 18, pp. 1681$1683,2020$.

[5] M. E. Karar, E. E.-D. Hemdan, and M. A. Shouman, "Cascaded deep learning classifiers for computeraided diagnosis of COVID-19 and pneumonia diseases in X-ray scans," Complex Intell. Syst., pp. 1-13, 2020.

[6] S. Mohammed, F. Alkinani, and Y. Hassan, "Automatic Computer Aided Diagnostic for COVID-19 Based on Chest X-Ray Image and Particle Swarm Intelligence,” Int. J. Intell. Eng. Syst., vol. 13, no. 5, pp. 63-73, 2020.

[7] E. J. Hwang, H. Kim, S. H. Yoon, J. M. Goo, and C. M. Park, "Implementation of a Deep Learning-Based Computer-Aided Detection System for the Interpretation of Chest Radiographs in Patients Suspected for COVID-19," Korean J. Radiol., vol. 21, 2020.

[8] A. Abbas, M. M. Abdelsamea, and M. M. Gaber, "Classification of COVID-19 in chest X-ray images using DeTraC deep convolutional neural network," arXiv Prepr. arXiv2003.13815, 2020.

[9] T. Mahmud, M. A. Rahman, and S. A. Fattah, "CovXNet: A multi-dilation convolutional neural network for automatic COVID-19 and other pneumonia detection from chest X-ray images with transferable multi- 
JSAI: Journal Scientific and Applied Informatics

Vol. 4, No. 2, Juni 2021, hal. 147 153

E-ISSN: 2614-3054; P-ISSN: 2614-3062, accredited by Kemenristekdikti, Sinta 5

DOI: 10.36085

receptive feature optimization," Comput. Biol. Med., vol. 122, p. 103869, 2020.

[10] G. Marques, D. Agarwal, and I. de la Torre Díez, "Automated medical diagnosis of COVID-19 through EfficientNet convolutional neural network," Appl. Soft Comput., vol. 96, p. 106691, 2020.

[11] J. P. Cohen, P. Morrison, L. Dao, K. Roth, T. Q. Duong, and M. Ghassemi, "Covid-19 image data collection: Prospective predictions are the future," arXiv Prepr. arXiv2006.11988, 2020. 